\title{
MANIFESTATIONS OF OXIDATIVE STRESS AND MOLECULAR DAMAGES IN OVARIAN CANCER TISSUE
}

\author{
H. I. FALFUSHYNSKA ${ }^{1,2}$, L. L. GNATYSHYNA ${ }^{1,2}$, H. V. DENEHA ${ }^{1}$, \\ O. Y. OSADCHUK ${ }^{1}$, O. B. STOLIAR \\ ${ }^{1}$ Volodymyr Hnatiuk Ternopil National Pedagogical University, Ukraine; \\ e-mail: halynka.f@gmail.com; \\ ${ }^{2}$ I.Ya. Horbachevsky Ternopil State Medical University, Ukraine
}

Indices of oxidative stress are recognized molecular markers and prognostic criteria for malignant transformation of tissue, but their value depends on the type of tumor and the stage of its development. The goal of this study was to clarify the relationship between the characteristics of the oxidative stress system including metal-associated ones and the cytotoxicity manifestations in neoplastically transformed human ovarian tissue. The highest level of Mn-superoxide dismutase activity (by 630\%) and metallothionein protein (MT, 100\%) has been estimated for the first time in malignant ovarian tissue compared to normal ovarian tissue. The researchers have also found a much higher level of oxy-radical formation (by 332\%), a lower activity of catalase (by 49\%) and a lower level of reduced glutathione (by 46\%) and its redox index (0.84 versus 0.89 in the control) in tumor tissue. Under the relatively stable content of zinc, copper and cadmium in MTs, the content of zinc and especially copper in a form non-binding with MTs was significantly lower in the malignant tissue compared to normal one while the content of cadmium was higher. A discriminant analysis of all definable parameters revealed that the higher content of the products of oxidative destruction of proteins, lipids, fragmented DNA and the activity of cathepsin D, especially in its free form (by 235\%), are the main characteristic signs of malignant ovarian tissue.

Ke y word s: ovarian cancer, oxidative stress, apoptosis, metallothionein, glutathione, cathepsin D, copper, zinc.

$\mathrm{O}$ varian cancer dominates among the death causes of malignant tumors. In particular, according to the International Agency for Cancer Research, more than 165 thousand of newly diagnosed cases of ovarian cancer are registered each year over the world. This disease is the cause of death for more than 100 thousand women [1]. Currently there are no screening programs for precancerous and malignant ovarian pathology diagnostic, with the help of which specialists could have reduced the incidence and fatalities of this disease [2]. Therefore, the search and development of pathogenetically grounded methods of early diagnosis and treatment of ovarian pathology are the urgent issues of modern medical biochemistry, gynecology and oncology.

Ovarian cancer has an especially high ability to metastasize, which defines the clinical course of this disease $[3,4]$. The main determinants of the invasiveness and metastatic potential of malignant cells include proteolytic enzymes involved in degradation of the membranes and extracellular matrix. Among this group of enzymes, an estrogen induced lysosomal aspartyl protease cathepsin D deserves special attention. It plays a central role in the catabolism of proteins, destruction of tissue architecture and indirect tumor progression via growth factors and p53 protein expression [4]. Cathepsin D is expressed and activated in cell lines of human breast and ovarian cancer, moreover, a high content of this enzyme is a recognized marker of an adverse prognosis $[3,4]$. Cathepsin D release from lysosomes may result from the oxidative destruction of membranes, but the relationships between these phenomena are not established $[4,5]$.

It is reported that in the pathological conditions in a cell, including malignant tumors resulted from a number of endogenous factors, such as mitochondrial dysfunction of malignant cells, the concentration of reactive oxygen species may significantly increase [6]. These species modulate the proliferative activity of cells, cause destructive changes in the biological membranes, cellular compartments etc. For example, 
HCC1937 cell line of human breast cancer contains a high level of hydrogen peroxide, which promotes the survival and resistance of cancer cells and inhibits their removal by apoptosis [7]. Similar results were obtained for other cancers as well [8], while the information on the molecular mechanisms of pro-oxidative changes in ovarian cancer is limited. A significant contribution to the development of oxidative stress may be caused by imbalance of the content of transition metals that are capable of generating radicals in the Fenton reaction and/or influencing the redox state of the cell by binding to cellular thiols [9]. Therefore, the goal of our study was to determine a functional state of the antioxidant defense system as well as the stress-sensitive and metal-binding thiols in conjunction with the cytotoxicity manifestations in malignant ovarian tissue samples and in ovarian tissue samples of people not affected by the relevant gynecologic pathology.

\section{Materials and Methods}

For this research we used the intraoperative samples taken from the tumor core $(10 \times 10 \mathrm{~mm})$ of 15 newly diagnosed patients of reproductive age who had been operated for epithelial ovarian cancer at the Gynecological Department of the Ternopil Regional Oncological Dispensary. Cancer pathology was verified histologically. According to FIGO classification, all diagnosed patients had stage III disease. None of the operated oncologic female patients had been previously treated with platinum-based drugs (cisplatin/carboplatin/cycloplatam) or cyclophosphamide. Ovarian tissues of 15 females who died in the age of 22 to 35 years and were not affected by the relevant pathology during the sectional study, were taken as controls. The period from death to collection of samples was not more than six hours. All experimental studies were conducted in accordance with the rules of the National Congress on Bioethics (Kyiv, 2000) and the decision of the Commission on Bioethics of the Ternopil State Medical University (N 3, 2013).

All the procedures on tissues were carried out at $4{ }^{\circ} \mathrm{C}$. All the reagents, except those specified below, were produced by "Synbias", "chemically pure” grade.

To determine the parameters of the antioxidant defense system state, Ovarian tissue samples were homogenized (1:10 w:v) in $0.1 \mathrm{M} \mathrm{pH} 7.4$ phosphate buffer containing $100 \mathrm{mM} \mathrm{KCl,} 1 \mathrm{mM}$ EDTA and $0.1 \mathrm{mM}$ PMSF to inhibit proteolysis. Homogenization was carried out at $4{ }^{\circ} \mathrm{C}$ using $12-15$ strokes of a motor driven Teflon Potter-Elvehjem homogenizer. To determine the content of oxyradicals, we prepared $10 \%$ tissue homogenate in HEPES-sucrose buffer, $\mathrm{pH}$ 7.4. The determination was conducted in the soluble fraction of homogenate, which had been received to determine superoxide dismutase (SOD) and catalase (CAT) as a result of centrifugation of homogenate within $10 \mathrm{~min}$ at $6000 \mathrm{~g}$ (S6), to determine the level of oxygen radicals - as a result of its centrifugation within $45 \mathrm{~min}$ at $12000 \mathrm{~g}$ (S12) and to determine the concentration of metallothioneins within $45 \mathrm{~min}$ at $16000 \mathrm{~g}$ (S16).

Superoxide dismutase activity (SOD) (EC 1.15.1.1) was measured by a decrease in the rate of the reduction of Nitrotetrazolium blue in the presence of phenazine methosulfate and NADH [10]. To determine the activity of Mn-SOD, S6 fraction was previously kept at $0^{\circ} \mathrm{C}$ in the presence of $5 \mathrm{mM} \mathrm{KCN}$ for $60 \mathrm{~min}$, which caused a total suppression of $\mathrm{Cu}$, Zn-SOD activity with the following determination of activity by the method [11]. The activity of $\mathrm{Cu}, \mathrm{Zn}-$ SOD was calculated by the difference in the activities of total SOD and Mn-SOD. Enzymatic activity was expressed in conventional units (CU). An enzyme's activity, which was able to cause a decrease in optical density in the process of the reduction of Nitrotetrazolium blue in 50\% test sample per $1 \mathrm{mg}$ of protein from the homogenate in soluble form, was taken as $1 \mathrm{CU}$.

Catalase activity (EC 1.11.1.6) was measured in S6 fraction by Aebi method [12], which is based on the decomposition of hydrogen peroxide with the catalase derived from the sample. The test mixture contained $50 \mathrm{mg}$ of protein in $50 \mathrm{mM}$ K-phosphate buffer, $\mathrm{pH} 7.0$ in the presence of $15 \mathrm{mM}$ of $\mathrm{H}_{2} \mathrm{O}_{2}$ in the total volume of $3.0 \mathrm{ml}$. The reaction was initiated by adding the appropriate volume of $\mathrm{S} 6$ fraction, and then the absorbance at $240 \mathrm{~nm}$ within a 60 -second interval was measured. Enzymatic activity was calculated by the millimolar coefficient of the hydrogen peroxide's light absorbance $\left(\varepsilon=-0.04 \mathrm{mM}^{-1} \cdot \mathrm{cm}^{-1}\right)$ and expressed in $\mu \mathrm{mol} /(\mathrm{mg}$ of homogenate soluble protein.min.).

The content of total glutathione was determined in the homogenate tissue after complete reduction of glutathione through the use of glutathione reductase (Sigma, USA) and with the help of Ellman's reagent [13]. The level of 5-trinitrobenzoic acid was monitored with a spectrophotometer at $412 \mathrm{~nm}$. To determine the content of oxidized glutathione (GSSG), 2-vinylpyridine was added to the incubation mixture 
to a final concentration of $2 \%$ [14] 60 min before the determination, and the content of reduced glutathione (GSH) was calculated as the difference of concentrations between total glutathione and its oxidized forms. Redox index (RI) GSH was calculated as the ratio ([GSH] - [GSSG])/[GSH].

The determination of protein carbonyls (PC) was conducted due to their ability to form 2,4-dinitrophenylhydrazones under the homogenate incubation of ovarian tissue samples in the presence of $0.1 \mathrm{M}$ 2,4-dinitrophenylhydrazine in $\mathrm{HCl}, 2 \mathrm{M}$. The light absorbance was registered at $370 \mathrm{~nm}$ against the control, and the content of phenylhydrazone was calculated using a molar extinction coefficient of $2.1 \cdot 10^{4} \mathrm{M}^{-1} \cdot \mathrm{cm}^{-1}$ [15]. Lipid peroxidation was characterized by the products of interaction between deproteinized homogenate supernatant after precipitation of proteins with trichloroacetic acid (with final concentration of 5\%) from ovarian tissue samples and 2-thiobarbituric acid (TBA). The formation of TBAreactive substance (TBARS) was calculated by the intensity of the absorption of a pink-colored complex at $532 \mathrm{~nm}$ by the molar extinction coefficient of the complex equal to $\varepsilon=1.56 \cdot 10^{5} \mathrm{M}^{-1} \cdot \mathrm{cm}^{-1}$ [16].

The content of oxygen radicals in S12 fraction of the ovarian tissue was evaluated using the nonfluorescent derivative, dihydrorhodamine, which is converted to the fluorescent dye, rhodamine-123, after a reaction with reactive oxygen species. The fluorescence signal was detected by using a f-max fluorescence plate-reader [excitation $=485 \mathrm{~nm}$, emission $=538 \mathrm{~nm}$ ] immediately and after $20 \mathrm{~min}$ and used to determine the rate of ROS formation [17] and expressed in relative fluorescence units (RFU) per $1 \mathrm{mg}$ of protein.

The content of metallothioneins (MT) in S16 fraction of ovarian tissue was evaluated by the content of thiol groups (MT-SH) by the method of Viarengo et al. [18] with 5,5'-dithio-bis-2-nitrobenzoic acid (DTNB, Sigma, USA) after the chloroform-ethanol extraction of MT, and calculated assuming that $1 \mathrm{~mol}$ of MT contains the same amount of SH-groups as 20 moles of GSH [18]. The content of metals in the fraction of MT was determined after gel-permission chromatography on Sephadex G-50 [19]. MT content by its content of metals (MT-Me) was calculated by the modified Hamilton equation taking in account the stoichiometric nature of these metals' binding: $\mathrm{m}$ (metallothioneins $)=0.5(\mathrm{v}(\mathrm{Zn}, \mathrm{Cd}) \cdot \mathrm{M}(\mathrm{MT}) / 7+$ $v(\mathrm{Cu}) \cdot \mathrm{M}(\mathrm{MT}) / 12)(\mu \mathrm{g})$, where $v$ - the quantity of metal in MT, $\mu \mathrm{mol} / \mathrm{g}$ of tissue; M (MT) - MT molar mass $(7000 \mathrm{~g} / \mathrm{mol}), 7$ and 12 - the number of the according ions that bind to a molecule of MT under complete saturation [20].

DNA damage was determined by the content of the fragmented deproteinized DNA in the total DNA by the method of alkaline precipitation of $10 \%$ tissue homogenate in $50 \mathrm{mM}$ Tris-EDTA buffer, $\mathrm{pH} 8.0$, containing $0.5 \%$ sodium dodecyl sulfate (Sigma, USA). The supernatant contains damaged DNA molecules when the pellet contains protein and a whole DNA. DNA content in the supernatant and in the pellet was determined by the Hoescht dye in the presence of $0.4 \mathrm{M} \mathrm{NaCl}, 4 \mathrm{mM}$ of sodium cholate and $0.1 \mathrm{M}$ Tris ( $\mathrm{pH}$ 9.0) at the excitation wave (ex.) $=360 \mathrm{~nm}$ and emission (em.) $=450 \mathrm{~nm}$ [21]. The content of fragmented DNA was expressed as a percentage to the total DNA in the sample.

The enzymatic activity of cathepsin D (EC 3.4.23.5) was determined spectrophotometrically by the formation of acid-soluble products of hemoglobin enzymatic hydrolysis [22]. The reaction mixture contained 50\% tissue homogenate in $0.25 \mathrm{M}$ of sucrose solution and, as a substrate, $1 \%$ solution of bovine hemoglobin (Sigma, USA) in $0.1 \mathrm{M} \mathrm{ac-}$ etate buffer ( $\mathrm{pH}$ 5.0). The enzymatic reaction was stopped by adding $10 \%$ solution of trichloracetic acid up to a final concentration of $2 \%$. To determine the total activity of cathepsin D, the ovarian tissue homogenate sample was previously treated with $1 \%$ solution of Triton X-100 (Sigma, USA) for $10 \mathrm{~min}$ at $37{ }^{\circ} \mathrm{C}$. The control sample was incubated at $4{ }^{\circ} \mathrm{C}$ for 30 min before adding $10 \%$ trichloracetic acid solution. The activity of cathepsin D was calculated by the difference in the optical density of experimental and control samples at $280 \mathrm{~nm}$ wave length and expressed as nmol of tyrosine/(min $\times \mathrm{g}$ of tissue).

To determine the content of copper and zinc in the ovarian tissue and MT, the tissue samples and MT were digested in $65 \%$ pure nitric acid in a ratio of 1:5 (weight:volume) and determined using atomic absorption spectrophotometer C115 (Lomo, Russia). The content of cadmium was analyzed by atomic absorption spectrophotometer C-600 and expressed in $\mu \mathrm{g}$, or $\mu \mathrm{mol}$ to nmol per $1 \mathrm{~g}$ of the wet tissue [19].

The results of the measurements are presented as means \pm standard deviation $(\mathrm{M} \pm \mathrm{SD}$ ) for 15 samples of the malignant and control ovarian tissue. If the data was not normally distributed according to the Lilieford test, it had been transformed using the Box-Cox method [23]. For the data that were not normally distributed even after the transformation, 
non-parametric tests (Kruskall-Wallis ANOVA and Mann-Whitney $U$-test) were performed. Differences were considered significant if the probability of Type I error was less than 0.05 . The relationship between biochemical parameters of the ovarian tissue samples was evaluated using the principal component analysis (the value greater than 0.7 was considered as a probable factorial weight), discriminant analysis and correlation analysis (Pearson's correlation coefficient $\mathrm{r}$ under the probability of the value $P<0.05$ ). All statistical calculations were performed with Statistica v 10.0 and Excel for Windows-2007.

\section{Results and Discussion}

The results of an evaluation of antioxidant defense system state (Table 1) show that Mn-SOD activity in the malignant ovarian tissue is higher (by $630 \%$ ) than in controls, and the activity of $\mathrm{Cu}, \mathrm{Zn}$ SOD does not differ between the two groups. The catalase activity (by 49\%) and reduced glutathione level (by 46\%) are lower in the malignant tissue. At the same time, the intensity of the oxyradicals formation (by 332\%), the concentration of TBARS (by $100 \%$ ) and protein carbonyls (by 71\%) and the lowest concentration of oxidized glutathione (by 17\%) are higher in the tumor tissue compared to the control samples. Moreover, the redox index of glutathione is equal to 0.89 in control and 0.84 in the malignant tissue samples.
Analysis of the metals content in the ovarian tumors samples evidences that the content of copper (by 76\%) and zinc (by 47\%) is lower while the content of cadmium (by 1322\%) is higher than in the comparison group (Table 2). Therefore, the ratio of the concentrations of zinc, copper and cadmium in the tumor and the control tissue $(\mu \mathrm{mol} / \mathrm{g}$ of tissue) is fundamentally different: it is equal to 1.990:0.029:0.003 in control, and 1.050:0.007:0.040 in the malignant tissue.

The analysis of metals content in metallothioneins (Table 2) evidences that the differences between the groups, although they are presumable for copper and zinc, are substantially less than in the tissue. Thus, the content of zinc within the metallothioneins is higher in the malignant tissue than in control. However, the content of copper and cadmium in the composition of metallothioneins taken from the tumor tissue is less than one atom per molecule of this metal-binding protein [24]. From the comparison of the content of metals in the tissue and accumulated in the metallothioneins, we see that the massive imbalance of metals can be observed in the malignant ovarian tissue, including almost two times less content of zinc and five times less content of copper in non-binding form, whereas the content of such potentially toxic form of cadmium is nearly 40 times higher. The total content of the metal-binding form of metallothioneins (MT-Me) is commensurate

Ta ble 1. Biochemical parameters in the malignant and control ovarian tissues $(M \pm S D, n=15)$

\begin{tabular}{|c|c|c|}
\hline \multirow{2}{*}{ Parameter } & \multicolumn{2}{|c|}{ Groups } \\
\hline & Control tissue & Malignant tissue \\
\hline MT-SH content, $\mu \mathrm{g} \cdot \mathrm{g}^{-1}$ of tissue & $7.6 \pm 0.9$ & $15.3 \pm 1.8^{*}$ \\
\hline MT-Me content, $\mu \mathrm{g} \cdot \mathrm{g}^{-1}$ of tissue & $6.2 \pm 0.5$ & $6.8 \pm 0.8$ \\
\hline Reduced glutathione content, $\mu \mathrm{mol} \cdot \mathrm{g}^{-1}$ of tissue & $5.0 \pm 0.5$ & $2.7 \pm 0.5^{*}$ \\
\hline Oxidized glutathione content, $\mu \mathrm{mol} \cdot \mathrm{g}^{-1}$ of tissue & $0.6 \pm 0.1$ & $0.5 \pm 0.1^{*}$ \\
\hline $\mathrm{Cu}, \mathrm{Zn}-\mathrm{SOD}$ activity, CU$\cdot \mathrm{mg}^{-1}$ of protein & $1.5 \pm 0.3$ & $1.4 \pm 0.2$ \\
\hline Mn-SOD activity, CU. $\mathrm{mg}^{-1}$ of protein & $1.3 \pm 0.2$ & $9.5 \pm 0.8^{*}$ \\
\hline Catalase activity, $\mathrm{mmol} \cdot \mathrm{min}^{-1} \cdot \mathrm{mg}^{-1}$ of protein & $27.2 \pm 5.8$ & $18.2 \pm 1.5^{*}$ \\
\hline TBARS content, nmol $\cdot \mathrm{g}^{-1}$ of tissue & $18.0 \pm 2.1$ & $35.8 \pm 4.3^{*}$ \\
\hline Protein carbonyls level, $\mathrm{nmol} \cdot \mathrm{g}^{-1}$ of tissue & $1.4 \pm 0.3$ & $2.4 \pm 0.3^{*}$ \\
\hline Oxyradicals content, $\mathrm{RFU} \cdot \mathrm{mg}^{-1}$ of protein & $0.34 \pm 0.05$ & $1.47 \pm 0.27^{*}$ \\
\hline Total activity of cathepsin $\mathrm{D}, \mathrm{nmol} \cdot \mathrm{min}^{-1} \cdot \mathrm{g}^{-1}$ of tissue & $3.7 \pm 0.5$ & $8.5 \pm 0,9 *$ \\
\hline Free cathepsin D activity, $\mathrm{nmol} \cdot \mathrm{min}^{-1} \cdot \mathrm{g}^{-1}$ of tissue & $1.7 \pm 0.3$ & $5.7 \pm 0.8^{*}$ \\
\hline Content of fragmented DNA in total DNA, \% & $3.4 \pm 0.6$ & $6.8 \pm 0.5^{*}$ \\
\hline
\end{tabular}

Note. Here and Table 2: *differences compared with data for the intact ovarian tissue are presumable, $P<0.05$ 
Ta b le 2. Content of copper, zinc and cadmium in the ovarian tissue and metallothioneins $(M \pm S D, n=15)$

\begin{tabular}{lcc}
\hline \multicolumn{1}{c|}{ Parameter } & Control & Ovarian cancer \\
\hline $\mathrm{Cu}, \mu \mathrm{g} \cdot \mathrm{g}^{-1}$ of tissue & $1.83 \pm 0.19$ & $0.44 \pm 0.06^{*}$ \\
$\mathrm{Zn}, \mu \mathrm{g} \cdot \mathrm{g}^{-1}$ of tissue & $129.5 \pm 21.4$ & $68.3 \pm 19.0^{*}$ \\
$\mathrm{Cd}, \mu \mathrm{g} \cdot \mathrm{g}^{-1}$ of tissue & $0.32 \pm 0.04$ & $4.55 \pm 0.52^{*}$ \\
$\mathrm{Cu}-\mathrm{MT}, \mathrm{nmol} \cdot \mathrm{g}^{-1}$ of tissue & $2.2 \pm 0.2$ & $1.6 \pm 0.2^{*}$ \\
$\mathrm{Zn}-\mathrm{MT}, \mathrm{nmol} \cdot \mathrm{g}^{-1}$ of tissue & $9.2 \pm 1.2$ & $10.9 \pm 1.5^{*}$ \\
$\mathrm{Cd}-\mathrm{MT}, \mathrm{nmol} \cdot \mathrm{g}^{-1}$ of tissue & $2.0 \pm 0.2$ & $1.8 \pm 0.2$ \\
$\mathrm{Cu}: \mathrm{Zn}: \mathrm{Cd}(\mathrm{MT})$ & $1.0: 4.3: 0.9$ & $1.0: 7.0: 1.1$ \\
\hline
\end{tabular}

in the tissue samples from both groups, but the total content of metallothioneins protein determined by the content of thiols (MT-SH), is twice as high as in the malignant tissue compared to the intact tissue.

The signs of cytotoxicity are determined in the tumor tissue: an increased (compared to control) level of DNA fragmentation (by 100\%) and cathepsin D activity, both of its total (by 130\%) and free forms (by 235\%).

Using the method of principal component analysis (a subtype of the multivariate data analysis) allowed us to quantitatively prove the degree of the relationships between the changes of individual indicators in the tissue samples of comparison groups. As shown in Fig. 1, 63.47\% of the absolute values belong to Factors 1 and 2. By their values, MT-SH form a common cluster with the parameters of oxidative stress, cytotoxicity and cadmium, which are localized opposite to the group of essential metals, such as zinc and copper, catalase and reduced glutathione concerning Factor 1 (Fig. 1). This arrangement proves the affinity of the consistencies of the values changes within the cluster and their opposite character between the two clusters. With the help of stepwise discriminant analysis, the biochemical markers were defined, which differentiate the studied tissue samples with high reliability $(\mathrm{F}(10.13)=606.95$, $P<0.001)$. In particular, the characteristic signs of the malignant ovarian tissue include high activity values of free cathepsin D, the level of fragmented DNA, TBARS and protein carbonyls, as well as the low content of reduced glutathione in the tissue.

The concordance increase in Mn-SOD, MT$\mathrm{SH}$ and oxyradicals levels ( $r$ Mn-SOD/oxyradicals $)=0.91, P<0.001 ; r$ (MT-SH/oxyradicals $)=$ $0.85, P<0.001)$ in the malignant tissue indicates the alarm function of reactive oxygen species under the overexpression of these stress-dependent proteins
[25]. It is believed that such coordination may be based on the oxyradicals induced activation of MAP kinase pathway (MAPK) and a number of sensitive to oxidative stress transcription factors including Nrf2. The last one is assigned to the induction regulation of the cytoprotective genes block through binding to the antioxidant-responsive promoter element [26] and contributes to balancing the level of reactive oxygen species and therefore, the regulation of the transformed cells proliferation. The data on the role of metallothioneins and SOD overexpression in tumor cells is conflicting. Mitochondrial Mn-SOD, as a powerful antioxidant factor, plays a crucial role in cancer development. Many types of tumor cells are marked with the low protein and MnSOD activity, but some forms of tumors have a high level of both expression and activity of this enzyme, which can display different types and stages of cancer development [27]. Overexpression of both MnSOD and $\mathrm{Cu}, \mathrm{Zn}-\mathrm{SOD}$ as a result of gene therapy inhibits the growth of breast cancer cells in vitro and in vivo [28].

Such contradictory information also concerns the estimation of the MT role in cancer cells. MT are low-molecular weight, cysteine-rich (up to 30\% of amino acids), metal-keeping and stress proteins, which chelating zinc, cadmium and copper in cells. Because of the presence of three elements in the promoter of MT genes, metal-responsive, antioxidantresponsive and glucocorticoid- responsive, they are induced by metals, many stress factors and pro-oxidants and in vitro inhibit peroxide-radical processes [29-31]. The formation of the joint MT cluster with the parameters of oxidative stress in the ovarian tissue in the diagram obtained by the principal component analysis (Fig. 1), and the similarity of MT-Me index in the two groups evidences that under ovarian cancer MT function is connected to scavenge of re- 


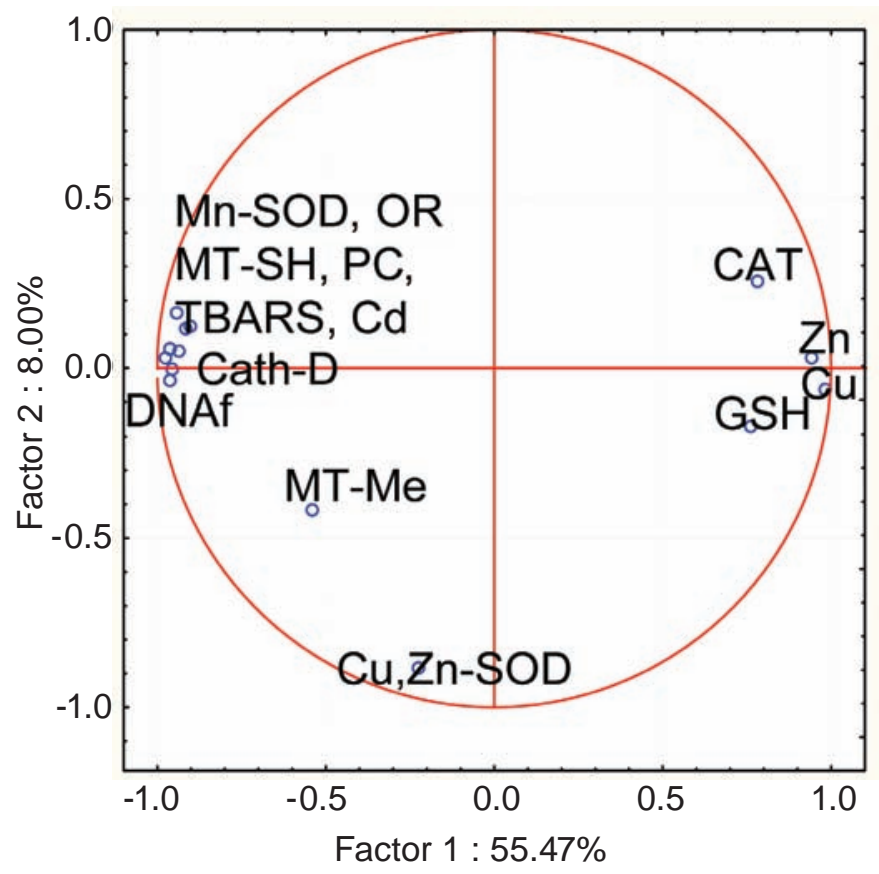

Fig. 1. The multivariate analysis of the metals content and the parameters of the oxidative stress system and apoptosis in the malignant and control ovarian tissues. Legend: MT-SH, content of metallothioneins by the level of thiols in the protein; MT-Me, content of metallothioneins by the level of metals (copper, zinc and cadmium) in the protein; $\mathrm{Cu}, \mathrm{Zn}, \mathrm{Cd}$, metal content in the tissue; GSH, reduced glutathione content; PC, protein carbonyls level; TBARS, TBA-reactive substance content; OR, oxyradicals content; $\mathrm{Cu}, \mathrm{Zn}$-/Mn-SOD, $\mathrm{Cu}, \mathrm{Zn}$-/ Mn superoxide dismutase activity; DNAf, DNA fragmentation; CAT - catalase activity; Cath-D, cathepsin D

active oxygen species $(r$ (MT-SH/oxyradicals) $=$ $0.85, P<0.001)$ more, than to binding of metals, which had been noted by us under thyroid pathology [32, 33]. At the same time, we know that more than $74 \%$ of carcinomas have lower MT level than normal mucosa. However, overexpression of MT under colon cancer and high protein content specified by immunochemical method (i.e. metal-binding form of MT-Me), under breast cancer is considered a sign of unfavorable prognosis of the disease, including the formation of metastases, and in the use of chemotherapy [34]. At least 10 genes encoding MT, are associated with breast cancer [34]. However, under testicular cancer, the high levels of MT defined immunochemically, is the evidence of a positive prognosis for the use of chemotherapy [35]. In addition, the isoforms composition of MT may determine the mechanism of cell death, moreover, MT-3 expression leads to the inhibition of the apoptosis and necrosis scenario development [36]. Thus, coordinated activation of Mn-SOD and increase of MT content, which is served as radicals scavenger, can not be interpreted uniquely in the studied pathology. Therefore, simultaneous increase in activity and/or contents of SOD and MT stress-related protein and parameters of prooxidant changes are observed in the tumor tissue. The reasons for the accumulation of the reactive oxygen intermediates can be both the depleted pool of glutathione and the imbalance between SOD activation and the inhibition of catalase activity, as evidenced by the negative correlation between these parameters $(r=-0.78, P<0.001)$ and the results of a multivariate analysis. Interrelations between SOD activities: catalase is six times higher in the malignant tissue than in control, which shows an insufficiently effective removal of hydrogen peroxide - a product of superoxide anion dismutation. It is commonly known, that with the participation of redox-active metals, mostly iron, hydrogen peroxide converts into highly reactive a hydroxyl radical [25]. In turn, the accumulation of oxygen radicals contributes to high proliferative capacity of the malignant cells.

The level of reduced glutathione and, even more, its redox index, refers to the prognostic signs of tumor growth because it largely controls the redox balance in cells, which, in turn, affects gene expression, cell differentiation, proliferation and 
apoptosis [37]. It is believed that the elevated level of glutathione indicates cellular resistance to chemotherapy with the help of cisplatin [38]. It is reported about the elevated glutathione level in the ovarian tumor tissue or its variability depending on the stage of tumor development (with an increase of the level in the process of tumor growth), while such characteristic is not observed under cervical cancer, or the reduction of glutathione is estimated in the process of tumor development [39]. Therefore, disregarding the large number of explorations, their results are ambiguous and, moreover, not correlated with other characteristics of the tissue. In our study, we clearly revealed common patterns of the changes of glutathione, copper and zinc levels in the ovarian tumor tissue (Fig. 1). These results indicate the irreversible exhaustion of glutathione, probably due to the removal of its essential ligands - zinc and copper from the tissue and minimizing of its redox index. The reduction of copper content in the tissue can be assessed as a positive sign because the chelation and removal of copper and other essential metals as well as glutathione is considered as an effective component in limiting tumor progression and angiogenesis and inflammation related to it [40], while the higher content of zinc, copper and glutathione in the malignant tissue indicates tumor progression [41]. Identifying destructive changes of proteins, lipids and DNA evidences of a significant degree of tissue damage, despite the activation of stress-sensitive proteins.

An increased content of cadmium in a nonbinding with MTs form occurred to be another damaging factor in the malignant tissue. An elevated level of cadmium was observed in the urine of women with breast cancer [42]. Our results let us estimate the relation between the level of cadmium in the ovarian tissue and the manifestations of oxidative damage to proteins and DNA:

$\mathrm{Cd}=-5.44+3.6 \times \mathrm{PC}^{*}-0.02 \times \mathrm{TBARS}-$ $-0.12 \times \mathrm{OR}+0.33 \mathrm{DNAf}^{*}, \mathrm{R}^{2}=0.90, \mathrm{~F}(4.19)=41.5$, $P<0.001$ (*parameter makes a presumable contribution to the mathematical model). Thus, it's obvious that an increase in cadmium content in ovaries became one of the factors of the radical-mediated pathological process and tumor growth.

Lysosomes are considered to be the most vulnerable cell targets for oxyradicals [43]. However, under the positive scenario, they induce autophagy a strictly regulated lysosomal pathway, which ensures the degradation of cytoplasmic structures and the cancer cells' death [43]. Regarding cathepsin D, its increased expression and release from lysosomes may both launch the apoptotic cascade with the death of damaged cells, functioning not as a protease, but as a signal factor, and inhibit apoptosis promoting malignant growth [44]. Moreover, peculiarly cathepsin D plays a key role in the progression of a number of malignant tumors $[4,44]$ and is a recognized independent marker of the unfavorable prognosis for various types of tumors $[44,45]$. We have shown that cathepsin D relates to determining factors of the comparison group differentiating in the malignant ovarian tissue.

Thus, a multi-marker analysis of stress-sensitive processes in the ovarian tumors allowed to determine the amount of features, under which the pathological changes in the malignant tissue are compounded - among them are the discoordination of the stress-dependent proteins activities, the imbalance of the sub-cellular distribution of copper, zinc and cadmium, as well as the activation and release of lysosomal cathepsin D.

The research was supported by the WestUkrainian Biomedical Center and the Ministry for Education and Science of Ukraine (State Budget Topic \#125B).

\section{ПРОЯВИ ОКИСНОГО СТРЕСУ ТА МОЛЕКУЛЯРНИХ УШКОДЖЕНЬ У РАКОВІЙ ТКАНИНІ ЯЙНИКІВ}

\section{Г. І. Фальфушинська ${ }^{1,2}$, Л. Л. Гнатишина ${ }^{1,2}$, Г. В. Денега ${ }^{1}$, О. Й. Осадчук ${ }^{1}$ О. Б. Столяр ${ }^{1}$}

\footnotetext{
${ }^{1}$ Тернопільський національний педагогічний університет імені Володимира Гнатюка, Україна; e-mail: halynka.f@gmail.com;

${ }^{2}$ ДВНЗ «Тернопільський державний медичний університет ім. І. Я Горбачевського», Україна
}

Показники окисного стресу є визнаними молекулярними маркерами та прогностичними критеріями злоякісного переродження тканини, проте їх виявлення залежать від типу пухлин і стадій їх розвитку. Метою дослідження було з'ясувати взаємозв'язок між характеристиками системи окисного стресу, у тому числі й металасоційованими, та проявами цитотоксичності в онкотрансформованій тканині яйників людини. Вперше встановлено вищий рівень $\mathrm{Mn}$ супероксиддисмутазної активності цитозолю (на $630 \%$ ) та протеїну металотіонеїну (МТ, на 100\%) у трансформованій тканині порівняно з неура- 
женою тканиною яйників. У пухлинній тканині значно вищий рівень утворення оксирадикалів (на 332\%), нижча активність каталази (на 49\%) та нижчий вміст відновленого глутатіону (на $46 \%)$ та його редокс індексу $(0,84$ проти 0,89 у контролі). За відносно стабільного вмісту цинку, купруму та кадмію у складі МТ, вміст цинку та, особливо, купруму у недепонованій формі істотно нижчий у трансформованій тканині, а вміст кадмію вищий. Дискримінантний аналіз всіх досліджуваних показників виявив, що підвищений вміст продуктів окисного ураження протеїнів, ліпідів, фрагментованої ДНК та активність катепсину Д, особливо його вільної форми (вище на 235\%) належить до головних характеристичних ознак онкотрансформованої тканини яйників.

К л юч ов і слов а: рак яйників, окисний стрес, апоптоз, металотіонеїни, глутатіон, катепсин Д, купрум, цинк.

\section{ПРОЯВЛЕНИЯ ОКИСЛИТЕЛЬНОГО СТРЕССА И МОЛЕКУЛЯРНЫХ ПОВРЕЖДЕНИЙ В РАКОВОЙ ТКАНИ ЯИЧнИКОВ}

\section{Г. И. Фальфушинская ${ }^{1,2}$, Л. Л. Гнатишина ${ }^{1,2}$, Г. В. Денега ${ }^{1}$ О. И. Осадчук ${ }^{1}$ О. Б. Столяр ${ }^{1}$}

\footnotetext{
${ }^{1}$ Тернопольский национальный педагогический университет имени Владимира Гнатюка, Украина; e-mail: halynka.f@gmail.com;

${ }^{2}$ ГВУЗ «Тернопольский государственный медицинский университет им. И. Я. Горбачевского», Украина
}

Показатели окислительного стресса являются признанными молекулярными маркерами и прогностическими критериями злокачественного перерождения ткани, однако их выраженность зависит от типа опухоли и стадий ее развития. Целью исследования было выяснение взаимосвязи между характеристиками окислительного стресса, в том числе и металлассоциированными, и проявлениями цитотоксичности в онкотрансформированной ткани яичников человека. Впервые установлен более высокий уровень активности Mn-супероксиддисмутазы (на 630\%) и протеина металлотионеина (МТ, на $100 \%$ ) в трансформированной ткани по сравнению с таковой у лиц с нетрансформированной тканью яичников (контроль). В опухолевой ткани уровень образования оксирадикалов (на $332 \%$ ) значительно выше, а активность каталазы (на 49\%), содержание восстановленного глутатиона (на $46 \%)$ и его редокс индекс - ниже $(0,84$ по сравнению с 0,89 в контроле). При относительно стабильном содержании цинка, меди и кадмия в составе МТ в опухолевой и здоровой ткани, содержание цинка и, особенно, меди в недепонированной форме в трансформированной ткани существенно ниже, чем в контроле, а содержание кадмия выше. Дискриминантный анализ всех исследуемых показателей выявил, что повышенное содержание продуктов окислительной деструкции протеинов, липидов, фрагментированной ДНК и активность катепсина Д, особенно его свободной формы (выше на 235\%) относится к главным характеристическим признакам онкотрансформированной ткани яичников.

Кл ю чевы е с лов а: рак яичников, окислительный стресс, апоптоз, металлотионеины, глутатион, катепсин Д, медь, цинк.

\section{References}

1. Howlader N., Noone A. M., Krapcho M., Garshell J., Neyman N., Altekruse S. F., Kosary C. L., Yu M., Ruhl J., Tatalovich Z., Cho H., Mariotto A., Lewis D. R., Chen H. S., Feuer E. J., Cronin K. A. SEER Cancer Statistics Review, 1975-2010, National Cancer Institute. Bethesda, MD, http://seer.cancer.gov/ csr/1975_2010/, based on November 2012 SEER data submission, posted to the SEER web site (accessed, April 2013).

2. Buys S. S., Partridge E., Black A., Johnson C. C., Lamerato L., Isaacs C., Reding D. J., Greenlee R. T., Yokochi L. A., Kessel B., Crawford E. D., Church T. R., Andriole G. L., Weissfeld J. L., Fouad M. N., Chia D., O'Brien B., Ragard L. R., Clapp J. D., Rathmell J. M., Riley T. L., Hartge P., Pinsky P. F., Zhu C. S., Izmirlian G., Kramer B. S., Miller A. B., Xu J. L., Prorok P. C., Gohagan J. K., Berg C. D. Effect of screening on ovarian cancer mortality: the Prostate, Lung, Colorectal and Ovarian (PLCO) Cancer Screening Randomized Controlled Trial. JAMA. 2011;305:2295-2303.

3. Galtier-Dereure F., Capony F., Maudelonde T., Rochefort $\mathrm{H}$. Estradiol stimulates cell growth and secretion of procathepsin D and a 120-kilodalton 
protein in human ovarian cancer cell line BG-1. J. Clin. Endocrinol. Metab. 1992;75(6):14971502.

4. Lösch A., Schindl M., Kohlberger P., Lahodny J., Breitenecker G., Horvat R., Birner P. Cathepsin $\mathrm{D}$ in ovarian cancer: prognostic value and correlation with p53 expression and microvessel density. Gynecol. Oncol. 2004;92(2):545-552.

5. Kågedal K., Johansson U., Ollinger K. The lysosomal protease cathepsin $\mathrm{D}$ mediates apoptosis induced by oxidative stress. FASEB $J$. 2001;15(9):1592-1594.

6. Mahalingaiah P. K., Singh K. P. Chronic oxidative stress increases growth and tumorigenic potential of MCF-7 breast cancer cells. PLoS One. 2014;9(1):e87371.

7. Martinez-Outschoorn U. E., Balliet R., Lin Zh., Whitaker-Menezes D., Birbe R. C., Bombonati A., Pavlides S., Lamb R., Sneddon S., Howell A., Sotgia F., Lisanti M. P. BRCA1 mutations drive oxidative stress and glycolysis in the tumor microenvironment: Implications for breast cancer prevention with antioxidant therapies. Cell Cycle. 2012;11(23):4402-4413.

8. Sung S. Y., Kubo H., Shigemura K., Arnold R. S., Logani S., Wang R., Konaka H., Nakagawa M., Mousses S., Amin M., Anderson C., Johnstone P., Petros J. A., Marshall F. F., Zhau H. E., Chung L. W. Oxidative stress induces ADAM9 protein expression in human prostate cancer cells. Cancer Res. 2006;66(19):9519-9526.

9. Baharvand M., Manifar S., Akkafan R., Mortazavi H., Sabour S. Serum levels of ferritin, copper, and zinc in patients with oral cancer. Biomed. J. 2014;37(5):331-336.

10. Beauchamp C., Fridovich I. Superoxide dismutase: improved assay and an assay applicable to acrylamide gels. Anal. Biochem. 1971;44(1):276-287.

11. Floreani M., Napoli E., Palatini P. Role of antioxidant defences in the species-specific response of isolated atria to menadione. Comp Biochem Physiol C Toxicol Pharmacol. 2002;132(2):143-151.

12. Aebi H. Catalase. In: Methods of Enzymatic Analysis. Ed.: H. U. Bergmeyer. London: Academic Press, 1974. P. 673-677.

13. Anderson M. E. Determination of glutathione and glutathione disulfide in biological samples. Methods Enzymol. 1985;113:548-55.

14. Griffith O. W. Determination of glutathione and glutathione disulfide using glutathione reductase and 2-vinylpyridine. Anal Biochem. 1980;106(1):207-212.

15. Lushchak V. I., Bagnyukova T. V., Lushchak O. V. Indices of oxidative stress. 1. TBA-reactive substances and carbonylproteins. Ukr. Biokhim. Zhurn. 2004;76(3):136-141. (In Ukrainian).

16. Ohkawa H., Ohishi N., Tagi K. Assay for lipid peroxides in animal tissues by thiobarbituric acid reaction. Anal. Biochem. 1979;95(2):351358.

17. Viarengo A., Burlando B., Cavaletto M., Marchi B., Ponzano E., Blasco J. Role of metallothionein against oxidative stress in the mussel Mytilus galloprovincialis. Am. J. Physiol. Regul. Physiol. 1999;277:R1612-R1619.

18. Viarengo A., Ponzano E., Dondero F., Fabbri R. A simple spectrophotometric method for metallothionein evaluation in marine organisms: an application to Mediterranean and Antarctic molluscs. Mar. Environ. Res. 1997;44:69-84.

19. Falfushynska H., Gnatyshyna L., Turta O., Stoliar O., Mitina N., Zaichenko A., Stoika R. Responses of hepatic metallothioneins and apoptotic activity in Carassius auratus gibelio witness a release of cobalt and zinc from waterborne nanoscale composites. Comp. Biochem. Physiol. C Toxicol. Pharmacol. 2014;160:66-74.

20. Nielson K. B., Winge D. R. Independence of the domains of metallothionein in metal binding. $J$. Biol. Chem. 1985;260(15):8698-8701.

21. Olive P. L. DNA precipitation assay: a rapid and simple method for detecting DNA damage in mammalian cells. Environ. Molec. Mutagen. 1988;11(4):487-495.

22. DingleJ.T., Barrett A. J., Weston P.D. Cathepsin D. Characteristics of immunoinhibition and the confirmation of a role in cartilage breakdown. Biochem. J. 1971;123(1):1-13.

23. Falfushynska H., Gnatyshyna L., Yurchak I., Sokolova I., Stoliar O. The effects of zinc nanooxide on cellular stress responses of the freshwater mussels Unio tumidus are modulated by elevated temperature and organic pollutants. Aquat. Toxicol. 2015;162:82-93.

24. Hamilton S. J., Mehrle P. M., Jones J. R. Cadmium-saturation technique for measuring metallothionein in brook trout. Trans. Am. Fish. Soc. 1987;116:541-550.

25. Lushchak V. I. Adaptive response to oxidative stress: Bacteria, fungi, plants and animals. 
Comp. Biochem. Physiol. C Toxicol. Pharmacol. 2011;153(2):175-190.

26. de Vries H. E., Witte M., Hondius D., Rozemuller A. J., Drukarch B., Hoozemans J., van Horssen J. Nrf2-induced antioxidant protection: a promising target to counteract ROSmediated damage in neurodegenerative disease? Free Radic. Biol. Med. 2008;45(10):1375-1383.

27. Dhar S. K., St. Clair D. K. Manganese superoxide dismutase regulation and cancer. Free Rad. Biol. Med. 2012;52(11-12):2209-2222.

28. Weydert C. J., Waugh T. A., Ritchie J. M., Iyer K. S., Smith J. L., Li L., Spitz D. R., Oberley L. W. Overexpression of manganese or copper-zinc superoxide dismutase inhibits breast cancer growth. Free Rad. Biol. Med. 2006;41(2):226-237.

29. Maret W. Redox biochemistry of mammalian metallothioneins. J. Biol. Inorg. Chem. 2011;16(7):1079-1086.

30. Raudenska M., Gumulec J., Podlaha O., Sztalmachova M., Babula P., Eckschlager T., Adam V., Kizek R., Masarik M. Metallothionein polymorphisms in pathological processes. Metallomics. 2014;6(1):55-68.

31. Surowiak P., Materna V., Maciejczyk A., Pudełko M., Markwitz E., Spaczyński M., Dietel M., Zabel M., Lage H. Nuclear metallothionein expression correlates with cisplatin resistance of ovarian cancer cells and poor clinical outcome. Virchows Arch. 2007;450(3):279-285.

32. Falfushynska H. I., Gnatyshyna L. L., Osadchuk O. Y., Shidlovsky V. O., Stoliar O. B. Trace elements storage and metallothioneins function peculiarities in human thyroid gland under transformation. Ukr. Biochem. J. 2014;86(3):107-113. (In Ukrainian).

33. Falfushynska H. I., Gnatyshyna L. L., Osadchuk D. V., Shidlovsky V. O., Stoliar O. B. Metal-binding function and antioxidant properties in human thyroid gland under iodine deficient nodular colloidal goiter. Ukr. Biokhim. Zhurn. 2011;83(6):92-97. (In Ukrainian).

34. Bay B.-H., Jin R., Huang J., Tan P.-H. Metallothionein as a prognostic biomarker in breast cancer. Exp. Biol. Med. 2006;231(9):15161521.

35. Eid H., Geczi L., Bodrogi I., Institoris E., Bak M. Do metallothioneins affect the response to treatment in testis cancers? J. Cancer Res.Clin. Oncol. 1998;124(1):31-36.
36. Somji S., Garrett S. H., Sens M. A., Gurel V., Sens D. A. Expression of metallothionein isoform 3 (mt-3) determines the choice between apoptotic or necrotic cell death in Cd12-exposed human proximal tubule cells. Toxicol. Sci. 2004;80:358-366.

37. Burhans W. C., Heintz N. H. The cell cycle is a redox cycle; linking phase-specific targets to cell fate. Free Radic. Biol. Med. 2009;47(9):12821293.

38. Okuno S., Sato H., Kuriyama-Matsumura K., Tamba M., Wang H., Sohda S., Hamada H., Yoshikawa H., Kondo T., Bannai S. Role of cystine transport in intracellular glutathione level and cisplatin resistance in human ovarian cancer cell lines. Br. J. Cancer. 2003;88(6):951956.

39. Gamcsik M. P., Kasibhatla M. S., Teeter S. D., Colvin O. M. Glutathione levels in human tumors. Biomarkers. 2012;17(8):671-691.

40. Goodman V. L., Brewer G. J., Merajver S. D. Copper deficiency as an anti-cancer strategy. Endocr. Relat. Cancer. 2004;11(2):255-263.

41. Valko M., Rhodes C. J., Moncol J.,Izakovic M., Mazur M. Free radicals, metals and antioxidants in oxidative stress-induced cancer. Chem. Biol. Interact. 2006;160(1):1-40.

42. Nagata C., Nagao Y., Nakamura K., Wada K., Tamai Y., Tsuji M., Yamamoto S., Kashiki Y. Cadmium exposure and the risk of breast cancer in Japanese women. Breast Cancer Res. Treat. 2013;138(1):235-239.

43. Yu C., Huang X., Xu Y., Li H., Su J., Zhong J., Kang J., Liu Y., Sun L.Lysosome dysfunction enhances oxidative stress-induced apoptosis through ubiquitinated protein accumulation in Hela cells. Anat. Rec. (Hoboken). 2013;296(1):3139.

44. Liaudet-Coopman E., Beaujouin M., Derocq D., Garcia M., Glondu-Lassis M., Laurent-Matha V., Prébois C., Rochefort H., Vignon F. Cathepsin D: newly discovered functions of a long-standing aspartic protease in cancer and apoptosis. Cancer Lett. 2006;237(2):167-179.

45. Garcia M., Platet N., Liaudet E., Laurent V., Derocq D., Brouillet J. P., Rochefort H. Biological and clinical significance of cathepsin D in breast cancer metastasis. Stem Cells. 1996;14(6):642650.

Received 02.02.2015 